УДК 343.9

\title{
СОСТОЯНИЕ СУАЕБНО-МЕАИЦИНСКОЙ ЭКСПЕРТИЗЫ КАК ИНАИКАТОР СТЕПЕНИ ЗАЩИЩЕННОСТИ СОЦИУМА ОТ БИОТЕРРОРИЗМА
}

\section{А.В. Ковалев ${ }^{1,2}$, В.Ю. ВлаАимиров ${ }^{1,3}$, С.А. Савчук ${ }^{1,4}$, Г.X. Романенко ${ }^{*}$}

\author{
${ }^{1}$ Российский центр судебно-медицинской экспертизы Минздрава России; \\ ${ }^{2}$ Российская медицинская академия непрерывного профессионального образования; \\ ${ }^{3}$ Московский университет МВД России им. В.Я. Кикотя; \\ ${ }^{4}$ НИИ фармации Первого Московского государственного медицинского университета им. И.М. Сеченова, \\ Москва, Россия \\ * Эл. nочma: romanenko@rc-sme.ru \\ Статья поступила в редакцию 03.04.2018; принята к печати 09.04.2018
}

В статЬе ПоАчеркивवется знवчимость сУАебно-экспертной профиАवктики преступлений против безопасности госуАарства и личности. ПривоАится пример использования материслов сУАебно-меАицинской экспертной Аеятельности ААя построения криминалистической характеристики престүплений, связанных с незаконным оборотом новых психоактивных веществ в раздичных регионах Российской ФеАерации и возникновением в результате их потребления массовых отравлений. Аелается вывоА о необходимости корректировки Аействующего законоАательства и выработке более эффективных мер защиты госуАарства и Аичности от гибриАных среАСтв поражения.

Ключевые слова: судебно-медицинская экспертиза, биотерроризм, массовые отравления, криминалистическая характеристика преступления, новые психоактивные вещества, эпидемии, эпизоотии, диверсия.

\section{FORENSIC EXPERTISE CONDITIONS}

\section{AS AN INDICATOR OF PROTECTION OF SOCIETY FROM BIOTERRORISM}

\section{A.V. Kovalev ${ }^{1,2}$, V.Yu. Vladimirovi, 3, S.A. Savchuk ${ }^{1,4}$, G.Kh. Romanenko ${ }^{1 *}$}

${ }^{1}$ Russian Center for Forensic Expertise of the Ministry of Health of the Russian Federation; ${ }^{2}$ Russian Medical Academy of Continuing Education; ${ }^{3}$ V.Ya. Kikotya University of the Ministry of the Interior of the Russian Federation; and ${ }^{4}$ Pharmacy Research Institute of I.M. Sechenov First State Medical University of Moscow,

Moscow, Russia

*E-mail: romanenko@rc-sme.ru

The significance of forensic services in preventing crimes against personal and public security is addressed. A case report is presented about using forensic data for characterization of crimes related to novel illicit psychoactive drug circulation and resulting massive poisonings in several regions of the Russian Federation. The conclusion is that current legislation should be amended for the sake of better protection of people and society from hybrid offenses.

Keywords: forensic expertise, bioterrorism, massive poisonings, crime characterization, novel illicit drugs, epidemics, epizootics, subversive acts. 
Роль судебно-экспертных учреждений различных федеральных органов исполнительной власти (ФОИВ) России в профилактике преступлений неоднократно подчеркивалась в криминалистической литературе. Термин «экспертная профилактика» наряду с профилактическими мероприятиями, инициируемыми и проводимыми органами расследования и дознания, подразделениями, осуществляющими оперативно-розыскную деятельность, известен давно. Однако в законе «О государственной судебно-экспертной деятельности в Российской Федерации» ${ }^{1}$ такое понятие применительно к определению целей и задач судебно-экспертной деятельности, к сожалению, отсутствует. На наш взгляд, это существенно обедняет палитру средств и методов, направленных на обеспечение безопасности государства и личности.

Как показывает судебно-медицинская практика, серьезные резервы в этой работе имеются у государственных судебно-медицинских экспертных учреждений Минздрава России (ГСМЭУ).

С учетом специфичности сферы деятельности ГСМЭУ особенно ярко это проявляется применительно к таким составам преступлений, в которых объектом посягательства являются общественные отношения в области обеспечения безопасности жизни и здоровья граждан.

В этой части особое место, на наш взгляд, среди составов преступлений диверсионнотеррористической направленности занимает ст. 281 «Диверсия» УК РФ ${ }^{2}$. Это определяется, прежде всего, тем обстоятельством, что в условиях навязанной нам гибридной войны на передний план выходит формирование и практическая реализация скрытых угроз, наносящих существенный вред состоянию защищенности государства и личности в различных сферах: обороны и безопасности государства, промышленности и энергетике, пищевой и фармацевтической безопасности и т. д.

Латентность в этих случаях обеспечивает возможность длительного и системного воздействия на те или иные общественно-политические процессы, приводящие к существенной деформации государственного и общественного устройства в условиях практической «безнаказанности».

Федеральный закон от 31 мая 2001 г. № 73-Ф3 «О государственной судебно-экспертной деятельности в Российской Федерации».

2 Уголовный кодекс Российской Федерации от 13.06.1996 № 63Ф3. http://www.consultant.ru/document/cons_doc_LAW_10699.
В этой связи, как мы уже неоднократно упоминали, вызывает удивление то, с какой легкостью в 1994 г. в Российской Федерации был изъят из уголовного законодательства состав преступления, именуемого диверсией, который охватывался ст. 68 УК РСФСР 3 . Еще большее удивление вызывает то обстоятельство, с какой непродуманностью была сформулирована новая редакция этого состава преступления (ст. 281 УК РФ) ${ }^{4}$, исключавшая наступление уголовной ответственности за такие деяния, как массовые отравления людей, в том числе со смертельным исходом, распространение эпидемий и эпизоотий.

Именно обобщение судебно-экспертной практики и, прежде всего, в части производства судебно-медицинских и судебно-химических экспертиз позволило нам провести ситуационное исследование социально-демографических процессов, имевших место в 2014 г. в ряде регионов России. Составленная на ее основе криминалистическая характеристика преступлений, связанных с массовым отравлением людей, способствовала более объективной оценке возникшей ситуации и формулированию практических рекомендаций по оперативному купированию подобных угроз в дальнейшем.

В сентябре-октябре 2014 г. (в течение 20 дней) в ряде регионов России произошли массовые отравления (879 человек), в том числе со смертельным исходом ( $\sim 3 \%)$. В подавляющем большинстве случаев органами здравоохранения ставился предварительный диагноз - «отравление неизвестным ядом». Лавинообразное нарастание отравлений произошло с 23 по 26 сентября, когда ежесуточно регистрировалось более 70 отравлений на территориях Кировской области и Ханты-Мансийского автономного округа. Причиной массовых отравлений явилось потребление психоактивных веществ (ПАВ) в виде курительных смесей [1].

В ходе проведения следственно-оперативных мероприятий было установлено, что в данных регионах произошел массовый сбыт новых ПАВ, не включенных в списки подконтрольных веществ, что значительно затрудняло привлечение виновных к уголовной ответственности за незаконный оборот наркотических средств и психотропных веществ (НСПВ), то есть явля-

\footnotetext{
3 Уголовный кодекс РСФСР (утв. ВС РСФСР 27.10.1960) (ред. федеральных законов от 01.07.94 № 10-Ф3, 13.12.94 № 59Ф3). http://www.consultant.ru/document/cons_doc_LAW_2950. Ссылка активна на 14.02.2018.

${ }^{4}$ Уголовный кодекс Российской Федерации от 13.06.1996 № 63Ф3. http://www.consultant.ru/document/cons_doc_LAW_10699.
} 
лось средством противодействия расследованию. Именно поэтому на первоначальном этапе проявления и развития этой токсической эпидемии должная реакция со стороны органов правоохраны не последовала. Лишь после того, как ситуация приобрела значительный общественный резонанс, органы наркоконтроля, МВД и СК России объединили свои усилия в разрешении этой нестандартной ситуации. Характер воздействия на организм человека свидетельствовал о наличии у нового ПАВ более выраженных токсических свойств, что не совсем характерно для наркобизнеса, так как в перспективе способствует естественному вытеснению такого препарата с криминального наркорынка другими НСПВ с более выраженными наркогенными свойствами и меньшей токсичностью. Исследование сбывавшегося наркодилерами в этих регионах нового ПАВ «MDMB(N)-BZ-F» показало, что введение фтора в алкильный фрагмент этого каннабимиметика существенно повысило психомиметичность соединения, что обусловило наступление более тяжелых психозов, грубую дезорганизацию поведения и резкое возрастание вероятности смерти от внешних причин (утопление, падение с высоты, аспирация рвотными массами и т. д.) [2]. Специфичность данного вещества, с учетом иных обстоятельств исследуемых событий, позволяла характеризовать его в соответствии с принятым в криминалистике определением оружия как средство, специально предназначенное и технически пригодное для поражения живой цели, не имеющее прямого назначения в быту или производстве и по своей токсичности представляющее такую же повышенную опасность, как иное отравляющее вещество аналогичного действия. Сравнение же этого ПАВ с отравляющими веществами раздражающего действия (ОВРД) свидетельствует о его гораздо большей токсичности.

Субъективно действия наркоторговцев были направлены на совершение преступлений, предусмотренных ст. 228-1 УК РФ ${ }^{5}$ в отношении молодых людей, проживающих на урбанизированных территориях с повышенным уровнем наркотизации, что способствовало скоротечности массового сбыта и потребления. Однако фактически, за счет применения высокотоксичного ПАВ, в результате их действий был достигнут другой эффект - массовые отравления людей, в том числе со смертельным исходом, что охватывалось ранее диспозицией ст. 68 УК РСФСР: «Совершение с целью осла-

5 Уголовный кодекс Российской Федерации от 13.06.1996 № 63Ф3. http://www.consultant.ru/document/cons_doc_LAW_10699 бления <..> государства <..> иных действий, направленных на массовое уничтожение людей, причинение телесных повреждений либо другого вреда их здоровью, <...> а равно совершение в тех же целях массовых отравлений...» ${ }^{6}$

Обращает на себя внимание состав преступных групп, деятельность которых привела к массовым отравлениям людей. Более 2/3 из них являлись гражданами сопредельного государства, проводящего в отношении России недружественную политику. Более того, характер поступления ПАВ на территорию России, маршруты перемещения соучастников указывали, что преступниками применяются единообразные хорошо проработанные и отлаженные схемы конспиративного характера, с более высокой по сравнению с обычной степенью организованности при совершении аналогичных наркопреступлений.

К сожалению, отсутствие в новой редакции статьи «Диверсия» (ст. 281 УК РФ) ${ }^{7}$ действий, направленных на «...причинение телесных повреждений либо другого вреда здоровью людей, ... а равно совершение в тех же целях массовых отравлений...» не позволило в тот период предпринять адекватные меры к лицам, спланировавшим и реализовавшим в отношении значительной части населения Российской Федерации действия, направленные на причинение массового вреда здоровью, а в конечном счете - на дестабилизацию общественных отношений в части регионов России.

Таким образом, криминалистическая характеристика преступления, разработанная нами на основе обобщения судебно-экспертной практики для оценки криминальной сущности описываемых событий, на наш взгляд, довольно убедительно проиллюстрировала ту поспешность, с которой законодатель «оформил исчезновение» из уголовного закона такого состава, как «Диверсия», в 1994 г., и непродуманность новой редакции этого состава преступления, возвращенного в уголовно-правовой инструментарий два года спустя, оставив без уголовно-правовой защиты от фактически диверсионных посягательств на жизнь и здоровье граждан и стабильность общественно-политического устройства государства.

В качестве практических рекомендаций нами было признано целесообразным следственнооперативному составу и судебно-экспертным

\footnotetext{
Уголовный кодекс РСФСР (утв. ВС РСФСР 27.10.1960) (ред. федеральных законов от 01.07.94 № 10-Ф3, 13.12.94 № 59Ф3). http://www.consultant.ru/document/cons_doc_LAW_2950. Уголовный кодекс Российской Федерации от 13.06.1996 № 63Ф3. http://www.consultant.ru/document/cons_doc_LAW_10699
} 
учреждениям, специализирующимся на исследовании НСПВ, во всех случаях проведения судебно-экспертных исследований новых, а при необходимости и традиционных НСПВ, наряду с наркогенностью исследуемого вещества определять и степень его токсичности с дифференциацией как собственной токсичности, так и приобретенной за счет каких-либо примесей. Это позволит своевременно выявлять и оперативно купировать потенциальные угрозы в части нанесения вреда здоровью и жизни людей, а также массовые отравления с трудно прогнозируемыми последствиями.

Закономерным этапом реализации выработанных по результатам проведенных исследований предложений является сформулированное в 2018 г. перед Российским центром судебно-медицинской экспертизы Минздрава России задание на проведение научно-исследовательской работы по теме «Судебно-медицинские исследования морфологических и токсикологических признаков острых отравлений синтетическими каннабиноидами (спайсами)», целью которой определено дальнейшее совершенствование лабораторных методов выявления и диагностики отравлений новыми психоактивными веществами.

Указанная работа будет проводиться межведомственной рабочей группой, в состав кото- рой планируется включить наиболее опытных специалистов - химиков, врачей - судебно-медицинских экспертов, врачей психиатров-наркологов, врачей-токсикологов, представителей правоохранительных органов и иных научных сотрудников, имеющих опыт в определении новых психоактивных веществ, оценке их наркогенных и токсических свойств, в том числе в условиях чрезвычайных ситуаций, связанных с массовыми отравлениями новыми психоактивными веществами.

Приведенный нами пример, на наш взгляд, убедительно свидетельствует о потенциальной, а может быть, уже латентно реализованной возможности причинения существенного вреда в социально-экономической сфере и обороноспособности России путем совершения аналогичных деяний, направленных на распространение эпидемий и эпизоотий на территории Российской Федерации. Это обстоятельство прямо указывает на необходимость организации планомерной и скоординированной научной деятельности в области криминалистики, судебной экспертизы, биологии, химии и других наук по приведению в адекватное состояние российского законодательства и выработку эффективных средств и методов защиты государства и личности от гибридных средств поражения.

\section{Аитература}

\section{Список русскоязычной литературы}

1. Владимиров ВЮ, Грекова ЕВ. О необходимости активизации научных исследований в сфере обеспечения борьбы с транснациональным наркобизнесом. В кн.: «Организационно-правовое регулирование безопасности жизнедеятельности в современном мире». Материалы международной научно-практической конференции 18-20 мая 2016 г., СПб.; 2016. С. 18-22.

2. Васильев АБ, Ризванова Л, Булыгина ИЕ и соавт. Опыт определения MDMB(N)-Bz-F в моче методами газовой хроматографии с моноквадрупольным масс-селективным детектированием и высокоэффективной жидкостной хроматографии с тандемным масс-селективным детектированием в случае массовых отравлений в гг. Сургут, Чебоксары, Киров. Наркология. 2014;(12):49-55.

\section{Общий список литературы/References \\ List}

1. Vladimirov VYu, Grekova YeV. [On the expediency to promote investigations related to combating trans-international illicit drug business]. In: OrganizatsionnoPravovoye Regulirovaniye Bezopasnosti Zhiznedeyatelnosti v Sovremennom Mire. Saint Petersburg; 2016. p. 18-22. (In Russ.)

2. Vasilyev AB, Rizvanova LN, Bulygina IE et al. [An experience of detection of $\mathrm{MDMB}(\mathrm{N})-\mathrm{Bz}-\mathrm{F}$ in urine using gas chromatography coupled with monoquadrupole mass-selective detection and high performance liquid chromatography coupled with tandem mass-selective detection in cases of mass poisoning in the cities of Surgut, Cheboksary, and Kirov]. Narkologiya. 2014;(12):49-55. (In Russ.) 